\title{
THE ART MUSIC'S ROAD FROM A CLOSED SYSTEM TO OPENNESS
}

\begin{abstract}
In this article we form a review-like vision of the development of Finnish music educational system. We use a philosophic-historic method combining the historical events into the educational theories and philosophical points of view. We use conceptions from music sociology and musicology combined in educational and partly historical point of view. The aim of the study is to find similar elements in the development of Finnish music education and positivistic and behaviouristic theories. The power structures and the ways of action are analyzed and estimated in spirit of discussion and opening new perspectives in the Finnish music education institutes which are struggling for survival in close future. Our findings show that old traditional ways of thinking and developing music education systems and organisations have come to the end of the road and new winds must start blowing. New research, the explosion-like development in music culture and music industry set new demands also to music education and institutions. The turtle defence no longer works and music culture must be seen as multidimensional many-sided part of every human being's life.
\end{abstract}

Keywords: musical world view; music education; art music education; music sociology

\section{INTRODUCTION}

The western art music characterized by rationality is crystallized in the hegemonic statement according to which it cannot be understood without special music analytical skills and abilities. It has been traditionally important for the representatives of art music to distinguish qualitatively valuable music from less valuable. Music in itself, though, does not include valueviewpoint; the question is about superimposing the values of art music into the whole field of music. The privileged status of art music has led into the situation where it never has been obliged to justify or give reasons for its own existence, quite the opposite: it has created the hierarchic regulations and been keeping the watch over the compliance of them. This axiomatic transcendent position has led in distortion of music research as the research focused for decades only on art music's great compositions and analyzing their surface structures through music theory and in the life of the great composer geniuses.

For this reason, it has not been until lately that researchers started examining for example the polymorphic relations of music and society, the paradigmatic development of music education or the formation of power relations and their effects in music education generally, but also the classification of music and evaluation of it, which, according to Herndon and Macleod (1981) were (and still are) the least researched areas in musicological and music educational research. Neglecting the communicative nature of music in society and addresses justifying old hegemonic 
traditions still complicate the developing of music education to rise to the challenges of the times. In this article we focus on historic points of view in the development of the structure of music education institutions which have their effects even to present day practice. In the beginning we focus on the roots of the phenomenon which lead to mid 1800 s.

\section{THE AIM OF THE STUDY}

To find similar elements in the development of Finnish music education and positivistic and behaviouristic theories.

\section{MATERIALS AND METHODS}

\section{The autonomy aesthetics determine the guidelines for music education}

In 1700-1800 Europe went through a history of ideologies and philosophies which raised questions about how music should be understood. The answers were searched in art philosophies in which the most important philosopher of his time, Immanuel Kant (1724-1804), also brought his bit. The thoughts of Kant formed and created a basis for the philosophy of enlightenment which later developed into positivism. His thoughts were based on the idea that all the problems, in the end, can be solved through reasoning. Kant wrote in his book Kritik der Urteilskraft (1790) (The critic of the judging ability), that beauty is born as a result of "altruistic evaluation" where the observer (receiver) does not bring (in the situation) anything that does not belong to the original art object. Because of his point of view Kant was seen as a predecessor of formalism which, among other things, had a strong influence in developing the European conservatoire institution system.

The formalistic paradigm was not focused until in Eduard Hanslick's (1825-1904) book Vom musikalishen Schönen (1854) (On the beauty in music) where he went against the aesthetics based on emotions and substance by saying that the core of music is in "the structures moving through the playing of music". According to Hanslick music belonged in the "field of understanding" and was not meant to bring up emotions because the listener should bypass his emotions and concentrate on examining the structures of music through his "own mind" (Hanslick, 1854; Iitti, 2002; 2003). According to him the Artistic music belongs above the entertainment because it exists "because of itself": a human being should serve art music instead of consuming it like the entertainment is used to doing. For the past 150 years these theses have been surprisingly close to the modern discourse of art music education.

Although in its days, the book by Hanslick was under quite strong dispute, it transferred the focus in music research and education from the emotional experiences to the examination of "pure music", which meant that the listener would not bring anything, meaning emotions, narratives or other experiences, from outside into the music listening process (Mantere, 1997; 2005). On the contrary: the listener concentrating on his own emotions was believed to be enthused by own feelings and emotions instead of music which would be left as an unessential point ${ }^{1}$. Hanslick was among the first authors, who focused on rational exploration and created, the conception of the superiority of analytical listening compared to other types (Iitti, 2003). He also spoke out about the body-mind problem in music concentrating on analytical thinking

\footnotetext{
${ }^{1}$ The way of thinking shows the idealistic thinking of the time more widely when we compare it to the modern point of view according to which music does not exist without the person who is experiencing it. The substance of music unavoidably develops through the emotions, associations and memories as well as images in mind. It also is good to notice that "bypassing" the emotions means an intensive emotional experience in connection with their rejection. The situation would be totally different if the structures would be explored through mere notation. The idea of aesthetic contemplation with the equation of music reception with the meditation comes from Plato and Plotinus who stated that "art experience belongs to meditation and that beauty belongs to field of intelligence, not in that of senses"
} 
although he wrote that it would make "a flourishing body only mere skin and bone" (Hanslick 1854, pp.9-10; Iitti, 2003).

The demand for "analytic research of music", which Hansick presented, reminds a lot of the thoughts of positivism which was spreading at the same time in the social sciences. Both took research a big step ahead through concentrating the main focus of researchers and teachers on experience-based analysis and making a direct separation from the metaphysic speculations. Hanslick's point of view strongly effected the canon of western art music and also had a great meaning in the development of music research and education.

Those thoughts still have their effect on our music educational system although a direct link between Hanslick and Finnish music education system cannot be found. It seems that the professional ideals for art music education have more in common with the traditions of Leipzig conservatory which were brought to Finland by a Finnish student who studied there.

\section{The first influences in music education came from Leipzig}

The father of Finnish music education, Martin Wegelius (1846-1906) had already noticed the poor level of Finnish music education when he left to Leipzig, for which reason he started to develop it following the German example after returning to Finland. Wegelius founded the first music school in Helsinki in 1882 (it became the Helsinki conservatory in 1924 and later, in 1939 - Sibelius Academy). Although Wegelius was known as a versatile cultured person, he was fundamentally a pedagogue and music theory teacher. Wegelius developed the conventions of music education all the way to university level, which also helped to organize music education also on other levels (Huttunen, 2002, 357-358).

Wegelius, who completed Master's studies at Helsinki University, always focused on the meaning of culture and education demanding students to take part in "general studies" which were giving music studies a new "objective shade of meaning". Wegelius always pointed out hard work and self-discipline, whereby not even sickness was a reason good enough to be absent from lessons. Wegelius stated that a student who is prone to sicknesses is not musically talented (Huttunen, 2002).

Also the Viborg music school ${ }^{2}$ founded by Russian-born Boris Sirob ${ }^{3}$ (Sirpo) (1893-1967) was a model to music schools which started after the WWII. Sirpo was a demanding teacher who developed the Viborg music school orchestra into an effective unit giving concerts in many European countries already in 1930s. Sibelius Academy and Viborg music school were the starting shots for the network of music schools which was not built until the 1950s and 1960s when the basis for the music education of today was laid. The music institutions founded in 1957 The Finnish association of Music institutes (SML) whose basic task for it was to organize the cooperation between music schools and to develop and unify the music education in the whole republic. A task which according to the internet pages of the association still is their main task (http:/www.musiikkioppilaitokset. org/?mid=42). The association immediately started to unify the teaching and organisation inside the music schools, for example through starting the formation of integrated curricula and demands for course examinations for instruments, music theory, analysis and history.

\footnotetext{
2 Sirpo led the music school until the start of the winter war. After the war the music school moved to Lahti giving an important fillip to the musical life of the town.

3 Sirob (or Sirpo) was also known through his student Heimo Haitto (1925-1999) who won the London violin contest in 1939 and performed in the autobiographic movie "Pikku pelimanni" (Small musician). Haitto moved to USA in 1940 where he built a career as a musician and a movie actor. Later Haitto, who lead a bohemian way of life circled USA for years and returned to Finland in 1980s continuing his musician career.
} 
The association (SML) tried to convince the decision-makers that a special law should be passed for the music schools. The representatives of SML negotiated continuously with the members of the Finnish parliament which finally led in 1968 to a new law (147/68) and statute (206/68) about the state grant ${ }^{4}$ for the music schools. These helped the economy of music schools on a solid ground. The law was an exceptional feat of strength: nothing similar was seen on any other field of art as it lifted the value of art music in a special standing compared to other fields of art education.

In addition to strong influential persons and excellent social relations an effective influence came from the strong cultural function ${ }^{5}$ of art music, as not only music educators, musicians and music students, but also the audience was seen owning a strong cultural capital through it. Supporting art music was also seen useful because it always had been going side by side with social and economic wellbeing, behind of which home, church and fatherland could be seen. The representatives of SML convinced the decision-makers that "art music is composed by geniuses and understood by intellectual, civilized and cultured people". For this reason music studies had an instrumental value as they kept youngsters away from the streets and made them get used to rules, regulations, competition, long-run working, coping with failures and targetoriented working. In addition to this music schools also ennobled a couple of top level artists from the mass of beginners showing the world ${ }^{6}$ that in Finland talented people live who give birth to international level conductors, composers and music performers.

In a course of time the politically neutral art music has been surrounded by a wide and extremely well organized centralisation of cultural, economic and social capital which supports and provides the music culture which they see as legitimate. The economic and political connections of art music have ensured its stable standing as the society changed around it. Because of the support from the highest deposition of society the art music's function, instead of being a power of social renovation, has become a power of conservation ennobling the values and ideals of European high culture.

Finnish music schools and institutions precisely followed the German Lehrplan type curriculum adapting the principles, which turned them into written long lists of examination tests made with Prussian exactitude ${ }^{7}$. A centrally planned leadership in making the curriculum cut all the free runners away from the education and gave every institute exactly the same teaching and examination requirements. The continuation of the system was guaranteed through the new law and statute as they made the examination certificate the only licence for working as a professional teacher in music schools and conservatoires.

Later the pedagogical thinking in music institutes was completed with behaviouristic

\footnotetext{
${ }_{4}$ The law was immediately criticized for neglecting the early childhood education and because the salaries of music school teachers were lower than the ones of Sibelius Academy teachers (Heimonen, 2005, 10).

5 This can be stated, although the idea of the law was to fulfil the social and areal equality (See Heimonen, 2005, 15).

${ }^{6}$ The same principle has been taken as a leading line for the newly founded Aalto University in Helsinki and as a target for the Finnish-brand (Suomi-brandi). The ideals of Aalto University have this way been widely copied from Sibelius Academy. The representatives of the so-called high culture see art music first of all as individual creativity armed with individualism and continuous conscious renovation of tradition which ennobles a human being also in many other ways. The debate about the intrinsic value of music in this situation is ostensible, because a lot of instrumental values, which hare in no connection with music, have been gathered around the intrinsic value of music.

${ }^{7}$ Although the Lehrplan principle dropped in history in 1980s the SML-association still holds tightly to the idea of giving strict lists of program suitable for each level of examinations.
} 
ideas. It is difficult to define weather it brought anything really new in teaching as it split the old-fashioned teaching contents into partial segments leading from easier to more difficult ones which were taught in teacher-controlled way focusing on rote learning. Because behaviourism followed the ideals of positivism as an "exact behavioural science" it was neither interested in the experiences of the pupils nor in culture or society as the main idea was to "remould the musical behaviour". For measuring the results it developed "objective indicators" which gave precise criteria for different level achievements and made the measuring of the results exact. The criteria for the course examinations of different levels were built accordingly of the ideals of positivism.

Later art music education adopted the hierarchical music conception ${ }^{8}$ which strongly reminded the autonomy aesthetics of Hanslick, saying that art music forms an autonomic artistic-aesthetic entity, which is completely separate and independent from the society, culture and audience as well as from music students. According to the hierarchic music conception the "eternal values" of western art music are defined through the over-social and over-historical basis of values forming criteria for evaluating and estimating all the music in the world (Karttunen, 1992; Lehtonen, 2005; see also Juvonen, 2000).

The ideological thoughts necessitated from hierarchic music conception gave excellent equipment for ruling over the field of music, but at the same time the self-sufficient idealism of values which was in direct connection with it damaged the art music institution which should have focused on critical analyses ${ }^{9}$ instead of cherishing the self-explanatory. The development of the structure of art music education system also can be construed through placing the system as a part of social development (see Karttunen, 1992; Cantell, 1993).

\section{The industrial production as an example for the rationality of music}

The music sociology explains changes in music and music culture through social circumstances and changes in them, which lead to a thought that music expresses, foresees and sometimes also changes the society. This way the economic and political system, the different power ambitions, values and ideologies as well as, for example, social inequality, incongruousness and even neuroticism are expressed in music.

According to the classic sociologist Max Weber (1958) the rationalistic development which started during the $1800 \mathrm{~s}$ is in direct connection with the spreading of capitalism. Weber thought that capitalism gave a birth to the harmony based on triad accords and formed the "production lines" for music education which reminded those in big factories. Also Reich $(1995,75)$ compares a modern educational institute to a factory where students move obeying a forehand made invariable program from one level to another just like the products delivered with a conveyor belt. The knowledge and skills are examined in special checking points where the faulty products are removed or returned to be remanoeuvred. Similarly those pupils with the best ability to learn and develop are moved to the lines that move faster. Like in mass production, also in music education the effectiveness and methodicalness form the essence of achievement (Rinne \& Salmi, 1998).

The art music institution has always had tight connections to the bureaucracy which also is favoured by capitalistic production model, because in Finland like in many other western

\footnotetext{
8 This was a self-explanatory fact which had to be adopted by every music student.

9 The problem is that in music schools and conservatoires people teach but do not make any kind of research which unavoidably conserves the old traditions. Also in the polytechnic institutions the acceptance of research besides teaching has been very contradictory at least in the beginning. The research is needed for uplifting selfreflection and to get rid of unnecessary activities, ideologies and habits.
} 
countries art music is the most bureaucratized type. The Weberian point of view where the handicraft of an individual is turned into mass production happened also in Finland where - not before the World War II - a fast structural change of society took place changing the agricultural society to a modern urban society.

The modern educational thinking is based on the belief that anything worth knowing can be explained and transferred to students by using a rational curriculum. The core in education is the rapidity, official rank and position in connection with guidance and supervision. According to sociological theories which swear in name of progress the world is an easily predictable place where people make rational decisions and choices (see Rinne \& Salmi, 1998).

In Finland the rationalization of music education happened the same way as in all fields of education. The aim of the standardization was social and regional equality as everyone could study the same course contents which were secured through examinations every year. The system also determined the age in which the course examinations should be done. The system of course examinations can be seen as a culmination of educational bureaucracy where the production-line thinking is taken to the highest possible level. The profitability was secured by using outsider censors whose task was to supervise that the course demands ${ }^{10}$ were correctly obeyed in every situation and in every region.

The contents of instrumental teaching course levels were specified in the program book published by SML where the "legitimate repertoire" for each course examination levels was presented. The difficulty of the program was defined through the examination levels starting from 1/3 examination continuing to the diploma which was passed in Sibelius-Academy. The course examination system took care of the suitable order of progression and also taught the student the "right idea" of remarkable music, composers, sound-ideals, techniques and practising. Also music theory teaching was organised in a series of packages of information taught in certain order including western art music theory, harmony and analysis techniques. The music theory teaching which functioned in the spirit of production-line techniques was carried out through its own "line" separated completely from instrumental teaching.

\section{Art music as a counterforce for the social turbulence of the $1960 \mathrm{~s}$}

The breakthrough of art music education took place in 1960s when traditional values also in Finland often faced new demands and needs. The changes meant among other things that people and matters which earlier were in marginal position in society started to require attention, space and rights. Also music culture went through a thorough change as the higher standard of living together with the spreading of radio receivers multiplied the music listening explosively. Also the rock music as a social exchanging power ${ }^{11}$ was emphasized because everywhere in the western world pop music had an unparalleled effect on the liberalization of society.

In those days pop and rock music went through an extremely productive and creative

\footnotetext{
${ }_{10}$ Until 1960s course examinations could be passed only in Sibelius-Academy, which caused lots of troubles. SML immediately started forming a system where course examinations could be passed in music schools and only the last qualification examinations were passed in Sibelius-Academy. In this standardized course examination system the censor had to be invited from Sibelius-Academy. This procedure was later given up because it stressed the resources of Sibelius-Academy. The whole system was based on the monopoly status of Sibelius-Academy where the censors supervised the level of students and also teachers in regional music schools and conservatoires (Ritaluoto, 1996).

${ }^{11}$ In this area a lot of attention has been given to rock festivals, for example Woodstock (1969) or Ruisrock (1970-) in Finland which brought the worldviews connected to rock music to the extensive consciousness of people.
} 
era which produced new, never before heard music to the reach of listeners. Together with pop and rock music for young people also a positive optimistic worldview arrived which focused on freedom, independence, criticalness against society, political activity, identity seeking and emphasizing a new kind of communality.

It is remarkable that in a time when Finnish society was getting free from agrarian society's narrow models of thinking it was art music that was negative to the changes. It is obvious that the "juvenile problem"12 projected to rock music by the media was one reason for the big support which art music education was given by society to grow up art music loving, decent youngsters, who would focus in art music (considered non-political) representing everlasting (read: rightwing conservative) values instead of joining restless movements and protesting against the values of society. According to Bourdieu (1984; 1985) nothing shows your class better than going to art music concerts or playing some "noble" musical instrument offered by classic music as a counterbalance for juvenile movements and political radicalism most strongly symbolized through rock as youngsters' own music ${ }^{13}$.

Also school teachers had declining attitude against youngsters' music and many thought that young people should be guided towards more civilizing art music instead of the disgusting strumming of rock. The basis of the prejudices of teachers was in addition to the lack of competence also the hope to return to "the culture of traditional singing of provincial songs". The polarity of cultures was a consequence of a collision of worldviews where the critical awareness of young people challenged the conservative worldview of art music. The parties of the conflict were rebellious rock and pop music on the one hand and art music supported by society and only enjoyed by a privileged minority on the other hand. The arguments of rulers were almost as if copied from Plato's Republic as the support given by society only concentrated on "a music which grows young people toward virtues and emotionally too stimulating or emasculating instruments ${ }^{14}$, scales or rhythms were forbidden" (see Heimonen, 2005, p.27.)

There was a wide mutual understanding among the establishment about not giving support to music which was morally daunting and undermining the peace of society. Especially jazz and rock music were under moralizing debate because new music was thought to tempt young people to unhealthy activities (experimental fuzz, political radicalism, underground movement, sex and drugs) which, undoubtedly, were strongly present as the culture of young people challenged the representatives of the dominant culture for a struggle.

In the middle of radical changes in 1960s art music became a bourgeois safe-world representing values which were seen to be above the social turbulences. In spite of this there was a tight arm wrestling between the camps which, for example, became concrete in Sibelius-

\footnotetext{
12 For the generations who experienced WW II the demands by young people were difficult to understand because they had spent their best years in the front line. There was also some kind of political consensus as the right-wing representatives saw juvenile movement as a warning of left-wing radicalism and at the same time left-wing representatives were quite suspicious about capitalistic rock culture which did not officially exist in the Soviet Union which was admired by many.

13 At the same time the spontaneous music instrument playing hobby outside music institutional teaching became explosively more common. For example, electric guitars were very expensive and hard to find those days and many of the most enthusiastic young musicians built their own instruments. Amplifiers were made from tube radio receivers and drum sets were made from cucumber cans. The most important thing was to be able to produce noise, although not everyone liked the artistic impression.

${ }_{14}$ This was the reason that rock music was not supported nor taught in music schools. A general conception about electric guitar was that it could produce terrible noise by its own if only someone would connect the electricity in it.
} 
Academy where students were not allowed to play in rock groups. The nuclear group of young radicals succeeded in challenging the representatives of art music in discussion by throwing naïve slogans like "a good pop hit song is better than a bad symphony" which forced the other side to make comments.

One of the most important partners in this discussion was composer Joonas Kokkonen who was awarded as an academician in 1963 which made his role as music politician even more important. Kokkonen belonged to the power keeping elite in the Finnish society because he had an important role in most of the main music- and culture field foundations ${ }^{15}$ which gave him possibility to concretely contribute to realizing his own visions.

As a conservative person Kokkonen (1992a, 1992b and 1992c) spoke out in his writings in many kinds of music political questions of which most important were, for instance, the renovation of Finnish school music education and building up the Finnish music school institution network, nationalizing Sibelius-Academy and regional policy of music life. The incisive comments by Kokkonen caused hard counter commentary which brought up many important ${ }^{16}$ points of pain opening conversation and new viewpoints.

As "the voice of art music" Kokkonen (1992a) polemized the float of "tap-music" from radio music channels, committed on the Beatlemania which he saw as a passing phenomenon, stamped the firs music sociologic doctoral thesis as a zero research ${ }^{17}$ and was also horrified about the thought that school music education could include pop songs ${ }^{18}$ (Aho, 1992). Kokkonen, who very much enjoyed being in the network of power, had unpredictable amount of supremacy ${ }^{19}$ in development and lining of Finnish music policy and music education. According to Kokkonen, art education should offer an intellectual alternative to the experiment-led pop cult which could not develop anyone's intellectual capital in any way.

\section{Who defines good music?}

Defining the value of music is a part of the struggle in field of cultural capital which

\footnotetext{
${ }^{15}$ It is ironical that Kokkonen (1992b) criticised music bureaucracy (which he called "byromania") although he himself was an owner of record number of chairmanships in the most important organizations of art-life (Finnish composers association, Finnish music council, Teosto, Sibelius-society, Wihuri trust, The administrative council of Finnish culture foundation, The association of Finnish symphony orchestras etc.) (Aho, 1992).

${ }^{16}$ Kokkonen (Aho, 1992) was active in debate when he also could have kept his mouth shut. One of his main dilemmas was that popular and artistic culture may live peacefully side by side as long as their different aims are clear to everyone (that is to say that no one would argue that pop culture could be art (writers' note)). This irritated especially young jazz and rock musicians who were producing artistically high level and sustainable music.

${ }_{17}$ Although Kokkonen did not mention the target of his critique against the doctoral thesis, by name he meant Seppo Toiviainen's (1970) thesis "Social and cultural conflicts" in which he examines music culture segments using Marxist sociological view. The thesis of 26-year old Toiviainen was extremely provocative as he wrote in the forewords that he is a strong-willed Marxist who finished his licentiate thesis to doctoral in only few weeks and also added the finishing touch by saying that there was an accelerating class war going on among the civilized high society. The book which was openly scornful against the hegemony was surely entertaining for the left wing representatives but it also raised furious resistance. Lehtonen (the other of two authors) can still remember that professor Jouko Tolonen (who acted as an extra opponent in the dissertation) every time lost his temper when the discussion touched the subject. There were many weaknesses in the dissertation, but it represented a new way of research in musicology which worked as an example for Lehtonen in his master's graduate thesis.

18 The critique was aimed against the irrational world view in pop songs which could not be promoted by society.

19 The status of Kokkonen was so undisputable that he was even called "Kekkonen of music" and "ViceSibelius".
} 
includes both the power fight inside the ruling class but also the civilising of the masses from above $^{20}$. The trump card of art music was thought to be the high quality, but the problem was the point of view and the actor in defining the quality.

Latterly a question has risen whether the art music education should change together as the music culture changes or can it still lean on the tradition of western high culture. Certainly some changes have taken place as some teachers and institutions have renewed their ways of action, but the organisation still has a lot of historical baggage which is difficult to change.

The autonomy aesthetics and the hierarchic music conception have made art music education with the strong support of leading class of society "a closed field" which has its own inner orderliness, effective production methods and a recognized standing in society. The organisations supported by society with the specialist systems keep the rivals in discipline and guide the measures of support, grants, awards and special prizes to right targets. The problem is that the whole organisation is based on the inheritance of the civilized bourgeoisie of $1800 \mathrm{~s}$ which was tuned up through capitalistic mass production including autonomy aesthetics and valueidealism and students are still socialized into its hermetical world view (see Karttunen, 1992).

The rules and regulations developed by art music itself have carried the hermetical development even further. This has led to a situation where art music was raised above estimation as it created its own norms for the estimation which also were controlled by itself ${ }^{21}$. According to these norms: 1) only those who have had a thorough art music education were competent enough to manifest their thoughts about them, and because 2) subjective experiences could not be stated as a basis of arguments, questions concerning art music had to be left to be solved by specialists representing it. The arguments and critique made by uninitiated could be ignored simply through saying that one does not know what one is talking about. For this exact reason the speech about art music is still monotonic and monophonic where the same arguments are repeated from year to year.

Art music representatives succeeded in establishing their point of view as right among the masses so effectively that many people still think that "music which sounds strange" is totally correct and the mistake of not understanding it is in their own knowledge and ability. The dominance of art music became so strong that the culture radicals of 1960s had to resort in carnivalism to undermine the hegemony.

Although the hegemonic principles seem ridiculous today, they were for a long time the only right truths which among others led to the fact that musicological research and music education neglected the social and cultural connections as well as music experiences and emotions as targets of research.

Music students were socialized in the superiority of hegemonic thoughts by showing the essential facts as self evident.

The principles still have effect which can be seen, for example, in the fact that music psychology belongs in cognitive musicology which is a part of general cognitive science paradigm connecting representatives of many different sciences (Louhivuori, 1992; Kaipainen, 1992). The spreading of cognitive paradigm which started in 1960s emphasizes the research of processing musical information which means that in this way cognitive research sees music more as "a

\footnotetext{
${ }^{20}$ It is difficult to believe that people whose own culture and consciousness were underestimated would become supporters of a strange culture offered to them from above.

${ }^{21}$ The norms of hegemony included a circular argument according to which only the representatives of art music institution were able to estimate questions concerning themselves.
} 
matter of understanding than emotional feeling"22.

The "truths" about the superiority of the high culture modelled the attitudes and gave psychological weapons for repressing the cultural habits unsuitable for the program. This was done through banning and neglecting but also through evaluating, selecting and muzzling (Knuuttila, 1992). The hegemonic thoughts were indoctrinated into general thinking by using slogans which highlighted the contrasts: music/noise, art/entertainment, quality/quantity, valuable/worthless, serious/light, eternal/temporary, artistic/commercial etc. Cultural anthropologist Claude LéviStrauss (1964) wrote that people in any culture tend to outline reality through polarities.

Also the education split the knowledge and emotion (rational and irrational) to be opposites of each other. When music theory was seen as logical system like geometry and music playing as rational activity the musical experience was seen to be born from the mystic relationship between the genius composers and nature, fatherland or metaphysical self-reflection ${ }^{23}$ which was transferred to listener through the composition. The romantic composer genius admired by autonomy aesthetics is a prophet whose sacred mission is to transfer sound pictures from his own transcendental world to the listeners.

Splitting is an effective way of having an influence on people. Separating good and bad as opposites offers a strong feeling of being right which reduces the need for stock-taking. Art music has been surrounded with a general world view which offers answers to essential questions for people inside it.

Worldview means the inner representation of self, identity and conceptions about the surrounding world which has developed through all that an individual has experienced, learned, thought and emotionally felt. The world view gives significance for living and guides our thoughts about what is important, insignificant or disagreeable. Also selecting and processing information is based on knowledge and emotional clues through which emotional experiences colour our cognitive activities (Karttunen, 1992).

The world view may be open or closed. An open world view needs supplements which means continuing seeking and assimilating of new musical significances. A closed world view is stable, permanent and self-contained where the unsuitable substances are strictly resisted and only right style musical substances, ideas and thoughts which suit the world view are accepted inside. The difference between art and entertainment formed a demarcation line between different cultural habits for a long time ${ }^{24}$.

The basis of musical world view is formed in childhood where the "cultural bath" from home takes care of the continuity of values. Also music education is said to be more effective if it is starts in early childhood ${ }^{25}$. It is usual that ideological organisations try to recruit new members already during childhood when the essentials of world view are built. An important age is also puberty when the enculturation process is feverish and when the basic world view for adulthood is formed. This means that it is no wonder that art music education supported by society started

\footnotetext{
${ }_{22}$ According to modern conceptions emotion and knowledge are not seen as polarities to each other anymore but they are in close connection, for example, in our observation processes.

${ }^{23}$ This is the spirit of obituary for Sibelius written by Kokkonen 21.09.1957.

${ }^{24}$ In reality the situation never occurred as black and white as professor Tolonen told that he had played light music in restaurants of Helsinki getting a little extra money like many other teachers and students of SibeliusAcademy did those days. Officially these border lines were maintained and for example entertainment music composer Toivo Kärki said in a TV interview that entertainment music was given no appreciation in 1950s.

${ }^{25}$ We have not found any research about this although it is seen in concert presentations (reminding more CV) of many artists.
} 
to rival with the temptation of pop cult in 1960s and 1970s.

The power position of art music still is in connection with strong resistance which tries to remind everyone that (1) dilettanti are not competent enough to understand art music and (2) they do not even know the criteria for estimating it. The critique of art music bounced away for long thanks to using this turtle defence method so that the only way for the radicals in 1960s was to change the rules of the game when they commented categorical statements on the absolute superiority of art music. They used absurd arguments like, for example, saying that "Iitin Tiltu" (an old war time propaganda song) is approximately as high quality as "The victory of Wellington"26 (Beethoven).

From time to time the representatives of art music also demonstrated their status by understating the value of pop culture which was positioned under them and which was seen as unnecessary form of culture in spirit of colonialist style assimilated by "popular enlightenment work" 27 . So, it was not a wonder that the thesis of Toiviainen (1970) which openly ridiculed the hegemony ${ }^{28}$ started a furious power struggle during which there were even attempts to prevent the publication of the thesis. The struggle began with the arm wrestling about the permission to publication and continued with the arguing during the dissertation situation which resembled a riot.

In the beginning of 1970 s the Tampere University was stamped on as radical left which made the thesis of Toiviainen most provocative as even the talk about class society ${ }^{29}$ was seen as old-fashioned in 1970s because Finland already had moved into a general culture where differences between social classes were not as radical as before anymore. Since 1960s the conflict was more between the generations which started between the war and depression generation and their children. Although the analyse is purpose-oriented and artless in Toiviainen's thesis, he still hit the nail on the head as he criticized the relation between social and musical power using hegemony compared to that of culturally less powerful. It was a "class struggle" where the pent up rage erupted in the dissertation situation.

\section{Art music as a paradigm}

American philosopher Thomas S. Kuhn(1922-1996) started a wide science philosophical debate when he published the book "The structure of the scientific revolution" concentrating on science history and growth of scientific knowledge (Kuhn, 1962; 1994). In the book he started using a new conception of paradigm which meant a self-evidently ruling scientific basic conception which changes as a revolution takes place. This points out that scientific knowledge does not grow evenly and cumulatively but there are sudden radical changes in its development.

According to Kuhn the paradigm which is predominant defends its own position by rejecting all critics and leaving research problems, methods and research results differing from

26 "The Victory of Wellington" is commonly thought to be the worst composition by Beethoven.

${ }^{27}$ The nannying in popular enlightenment was seen, for example, in music library achievement where the music library manual (made by Seppo Nummi, a trusted man of Joonas Kokkonen) was used until 1970s. It guided the libraries to buy $90 \%$ of records in classical concert music and the last $10 \%$ could be jazz and entertainment music. The idea was to educate the listeners by bringing art music available to anyone (Karttunen, 1992).

${ }^{28}$ This can be said because many of the terms and conceptions used in thesis were meant to defy the representatives of the hegemony in "spirit of class struggle" and at the same time start debate based on the contradictions.

${ }^{29}$ Toiviainen even uses a concept "agricultural proletariat" (Toiviainen, 1970, 91) which did not exist anymore in Finland in 1970s. On the other hand the ambiguous conception "class struggle" used by Toiviainen may also refer to symbolic fight in field of music. 
itself as the "normal science" without any attention or visibility. The normal science rules in addition to research problems and methods also the funding, education, choices of working groups and awards. At the time when normal science is not anymore able to defend itself, a scientific revolution takes place and a new kind of normal science starts to evolve in the same way as before.

Kuhn sees $(1962 ; 1994)$ that elements coming outside science may also help reaching the crisis stage inside science. In addition to science political ambitions these may consist of social, cultural and political exchange factors which are adding new demands for the prevailing normal science.

The thesis by Toiviainen was a sign of a change in paradigm of music research. The book challenged the long survived normal science and caused a furious debate about how, from what starting points music could or should be allowed to be researched. Academician Joonas Kokkonen appeared as a spokesman for art music paradigm in the middle of the crises trying to reject the new point of view with his own authority and the hegemonic arguments which he used, but which, as the crises went further, started to seem weaker and weaker ${ }^{30}$. All this took place in a time full of prolific political activity and emancipation as the new ideas, theories and conceptual systems which spread in Finland, increased the consciousness which together with the worldwide (Vietnam War) crises demanded university students to take part in social achievement movements.

It is obvious that like positivism, the autonomy aesthetics and hierarchic music conception also came to the end of their road already as early as in 1960s when the same kind of crisis took place in art and music as was going on in human sciences where positivistic ideals and models started to change into "understanding conception of science". The change of paradigm may be called, for example, "the revolution of experiences" where a human being as a historical, experiencing, and emotional entity started to rise in focus of human sciences research. The constructivist picture of man spread in sciences seeing a human being as an independent builder of humanity and himself through emotionally coloured experiences.

Instead of "definite truths" 31 the new generation conception of real world was based on discussion through which new ways of outlining reality and environment were tried to be found and something was tried to be done actively for it. In the place of truths people were interested in points of view and their fertility. The idea was to rise up fresh looking points which never before had been under discussion. Unfortunately the golden days of discussion quickly dried and the positions froze both culturally and politically.

The similarity of autonomy aesthetics and positivism refers to an idea that Hanslick drew building materials for developing his aesthetic theory from positivism. The similarities are too obvious to be merely coincidental. In positivist research it is important that the researcher keeps distance to the aim of research which is analyzed through structural and other characteristic elements. An unbreakable rule is also that the researcher does not bring any new elements to the target; on the contrary, he/she should be able to cut down all the elements which are in connection

\footnotetext{
${ }^{30}$ One of the worst misjudgements made by Kokkonen was that he did non notice the artistic levels of youngsters' music and bundled everything he did not understand as anti-art which he called "pop cult". This defamed deeply young, rock, jazz and pop composers equipped with strong artistic ambitions who immediately started the resistance.

${ }^{31}$ Certainly especially political extreme movements leaned on "definite truths" and blind faith but these groups were left in the marginal of the great changing process.
} 
with subjective or personal experience ${ }^{32}$. The research was not allowed to change the object which should stay exactly same as it had been before starting the research process.

One of the principles was also that research could not be estimated or criticized by anyone else but the person who knew the positivist methods and research rules. This meant that positivist research could not be estimated using strange (to itself) non-scientific criteria and methods. In spite of this principle positivist researchers used their own methods unlimitedly for estimating all the other research work. One aim of positivism was to produce general and common regulations for all scientific research work trying to make sure that all research would be objective. The same ideas ruled also in autonomy aesthetics which apparently was inspired by positivism.

\section{RESULTS}

\section{The revolution of experience}

Music education has been ruled by hard values: the ethics of protestant work, principle of effectiveness and seeking the talented ones. As the possibilities of taking interest in music as a hobby have become wider and reachable to everyone these values have slowly changed into pluralism where the function of art has become producing more joy, creativity and freedom. Research also has separated from the superiority of hierarchic music conception and widened to the research of other cultures and other music styles which are examined in spirit of autonomic music research underlining their equality.

The development of music culture follows socio-economic development where changes take place when social conditions are fulfilled. In spite of that the organisations which have established their position are holding on to their status through resisting all the changes. In the post-modern world music has become more and more a part of consumption where art music is also consumed in the same way as all other music styles. The situation radically changed as the commercial mass production distribution system also inside art music lead to highlighting commercial interests and to the fact that records and music players could be provided almost anywhere ${ }^{33}$.

The border lines in music are disappearing as the new way of thinking focuses on breaking the borders. It is interesting to see if the old institutions are able to renew themselves or lose their younger listeners and become "musical museums without audience". Making music is not anymore a privilege ${ }^{34}$ of some selected groups of people, as new innovative music is produced continuously in different areas and for different audiences. Music as a hobby is in the centre of consuming music which underlines the communal, experiential, entertaining and therapeutic functions which are no longer seen as an opposite to a serious artistic hobby. The different segments of art also integrate as the combining of music, picture and movement become common side by side with traditional concert achievement.

In future no music can be in a special position; the status must always be earned. Music

\footnotetext{
32 This means using a one-dimensional picture of a man as it is impossible to research any target without personal experiences. We must also remember that cutting of personal experiences means experiential relationship with the target of the research. Behaviourism representing positivism reduced the human being as an unwilling and unemotional object.

33 Lehtonen (one of the two authors) lately bought a record including Uuno Klami's (a famous Finnish composer) Merikuvia (Sea pictures) from a local gas station where it was in the middle of women's tights, chocolate bars and antifreeze liquids for cars.

${ }^{34}$ Earlier the superiority of art music was proved through saying that it has developed the "formels" meaning the kind of models, which were taken in use in light music later.
} 
culture has become like a supermarket where life means consuming and selecting and where different commercial directions fight over the souls of people. There are new music schools in internet working side by side with traditional music schools and conservatoires with the exception that they are only "digital distance" 35 away from children. These net services are available any time when the consumer needs service or materials. The explosion in music supply has brought us unobserved in a situation where almost everyone somehow has music as a hobby. Very rare recordings are available for buying and loading through internet where also musical instruments can be ordered easily to any place far or close. We live in a situation where hierarchical music conception has turned upside down as art music has been become marginal and its position without the supply from society would be intolerable.

In the end we offer an example of recycling of age-old hegemonic arguments. This time the comments came from important influential persons in the field of art music, who were disappointed in the election of Chancellor in Sibelius-Academy. They wanted to declare their "deep concern about the tendency of music education today" According to them, art music education in Sibelius-Academy has gone badly downwards, and also in children's music education art music has only a marginal position. The list of signers only included one professor still working in Sibelius-Academy: professor Arto Noras, according to whom Sibelius-Academy has nowadays become like "a grocery or a department store" in which the core (of the institution founded in 1882), orchestral instruments, singing and composing have been ruined as the general subjects and other than art music teaching (meaning: jazz, ethno music and music education) have been getting their part of the resources (see Siren, 2009).

\section{CONCLUSIONS}

The argumentation in the public comment is based on a hierarchic music conception's self-evident allegations which the under-signed try to force using their authority in the way Joonas Kokkonen did in his day. The response coming from Chancellor Djupsjöbacka returns to the controversy between Helsinki music school, founded by Martin Wegelius, and orchestra school of Robert Kajanus, as they argued about the meaning of all-round education. Wegelius highlighted scholarship and all-round education as Kajanus only wanted to educate orchestra musicians. It is obvious that the only music university of Finland can no longer focus on being an institute educating merely art musicians as the modern music life demands much wider competence from new musicians. The world has changed but it is alarming that in discussion about music culture and music education always same age-old arguments are taken up again and again.

\section{REFERENCES}

Aho, K. (1992). Joonas Kokkonen musiikkikirjoittajana [Joonas Kokkonen as a music writer]. In J. Kokkonen, \& K.Aho (Ed.), Ihminen ja musiikki [Music and a human being]. Helsinki: Gaudeamus, pp. 8-13. (in Finnish).

Bourdieu, P. (1984). Distinction. A social critique of the judgment of taste. Cambridge: Harward University Press.

Bourdieu, P. (1985). Sosiologian kysymyksiä [Questions of sociology]. Tampere: Vastapaino. (in Finnish).

Cantell, T. (1992). Konserttimusiikki - mennyttä historiaa nykypäivässä. Etnomusikologian vuosikirja [Concert music - long gone history in modern days. Yearbook of Ethnomusicology] 4, 110-121. (in Finnish).

35 The Canadian pianist Glen Gould was a post-modern world's big visionary who spoke for electronic music making and teaching with electronic equipment long before it was possible in the modern format. 
Hanslick, E. (1854). Vom Musikalischen Schönen [On the beauty of music] (1854/1976). Leipzig: Faksimile edition. Darmstadt: Wissenschaftliche Buchgesellshaft, p.22. (in German).

Heimonen, M. (2005). Soivatko lait? Näkökulmia musiikkikasvatuksen filosofiaan [Can the laws be heard as music? Points of view in the history of music education], 13. Sibelius-Akatemia EST-julkaisusarja. (in Finnish).

Herndon, M., McLeod, N. (1981). Music as culture. Darby: Norwood Editions, 239.

Huttunen, M. (2002). Helsingin musiikkiopisto ja sen opettajat [The Music School of Helsinki, and it's teachers]. In M.Haapakoski, A.Heino, M.Huttunen, H-I.Lampila \& K.Maasalo (Eds.), Suomen musiikin historia. Esittävä säveltaide [The history of Finnish music. Performing music]. Helsinki: WSOY, pp.355-358. (in Finnish).

Iitti, S. (2002). Ruumis mielen vihollisena. Kriittinen näkökulma Hanslickin musiikin-estetiikkaan [Mind as an enemy of body a critical point of view into Hanslic's music aesthetics theory]. Musiikki, 4, 52-64. (in Finnish).

Iitti, K. (2003). Autonomiaestetiikka, formalismi ja Hanslickin Musiikin kauneudesta [Autonomy aesthetics formalism and Hanslic's on the beauty of music]. In J.Torvinen \& A.Padilla (Eds.), Musiikin filosofia ja estetiikka. Kirjoituksia taiteen ja populaarimusiikin merkityksistä [The music philosophy and aesthetics. Writings about the significances in art music and popular music]. Helsinki: Yliopistopaino, 83-107. (in Finnish).

Juvonen, A. (2000). Johnnyllakin on univormu, heimovaatteet ja -kampaus Musiikillisen erityisorientaation polku musiikkiminän, maailmankuvan sekä musiikkimaun heijastamina [...Also Johnny has a uniform tribal clothes and hairdo...special musical orientation path reflected through musical self conception, musical worldview and musical taste]. In Jyväskylä Studies in the Arts, 70. Jyväskylä: Jyväskylän yliopisto, 391. (in Finnish).

Kant, I. (1790/2008). Kritik der Urteilskraft [The critic of judgement]. Berlin: Akademie Verlag GmbH. (in German).

Kaipainen, M. (1992). Kognitiotieteen paradigman vaihdos ja musiikin tutkimus [The change of paradigm in cognition science and the research in musiclogy]. In J. Louhivuori \& A.Sormunen (Eds.), Kognitiivinen musiikkitiede [Cognitive musicology]. Jyväskylän yliopiston musiikkitieteen laitoksen julkaisusarja [Jyväskylä University Series of Musicological Publications], A: 8. (in Finnish).

Karttunen, S. (1992a). Musiikki kulttuurisessa tietoisuudessa [Music in the cultural knowledge]. Jyväskylän yliopiston nykykulttuurin tutkimusyksikön julkaisu [Publication of Modern Culture Research Unit University of Jyväskylä], 35. (in Finnish).

Kokkonen, J. (1992a). Radio ja ääniterrori. Suomalainen Suomi 9/1965 [Radio and terror of voice. The Finnish Finland]. In J. Kokkonen \& K.Aho (Ed.), Ihminen ja musiikki [Music and a human being], Helsinki: Gaudeamus, pp. 263-267. (in Finnish).

Kokkonen, J., (1992b). Byrokraatti - byromaani. Avaussanat Suomen kulttuurirahaston vuosijuhlassa [Abyrocrate a byromane? Opening words in Year Celebration of Cultural Funding, 7.2.1985. In J. Kokkonen, Ihminen ja musiikki [Music and a human being], Aho, K. (Ed.). Helsinki: Gaudeamus, pp.297-299. (in Finnish).

Kokkonen, J. (1992c). Ihminen ja musiikki [Music and a human being], Aho K. (Ed.). Helsinki: Gaudeamus Oy, 503. (in Finnish).

Kuhn, T. (1962). The structure of scientific revolutions. Chicago: The University of Chicago Press.

Kuhn, T. (1994). Tieteellisten vallankumousten rakenne [The structure of scientific revolutions]. Helsinki: Art House, 208. (in Finnish). 
Lehtonen, K. (2005). Maan korvessa kulkevi... Johdatus postmoderniin musiikkikasvatukseen [Leading to Postmodern Music Education]. Turun yliopiston kasvatustieteiden tiedekunnan julkaisuja [Publications of Turku University Faculty of Education], B: 73. (in Finnish).

Lévi-Strauss, C. (1964). Le cru et le cuit [The raw and the cooked]. Monologiques I [Monologues I], Paris: Plon, 341. (in French).

Louhivuori, J. (1992). Kognitiivinen musiikkitiede - Musiikkitieteen uusi tutkimusparadigma? [Cognitive musicology - a new paradigm for musicology]. In J.Louhivuori \& A.Sormunen (Eds.), Kognitiivinen musiikkitiede [Cognitive musicology]. Jyväskylän yliopiston musiikkitieteen laitoksen julkaisusarja [Publications of Jyväskylä University Department of Musicology]. A: 8, 262. (in Finnish).

Mantere, M. (1997). Musiikki kurssitutkinnossa [Music in course examinations]. Etnomusikologian vuosikirja [Yearbook of Ethnomusicology] 8, 117-141. (in Finnish).

Mantere, M. (2005). Kohti musiikkikokemuksen esteettistä teoriaa [Towards the aesthetic theory of musical experience]. In J.Torvinen \& A.Padilla (Eds.), Musiikin filosofia ja estetiikka. Kirjoituksia taiteen ja populaarin merkityksist $\ddot{a}$ [The philophy and aesthetics of music. Writings about the significances in art and popular music]. Helsinki: Yliopistopaino, 183-204. (in Finnish).

Reich, R. (1995). Rajaton maailma: yritysten ja kansallisvaltioiden uudet pelisä̈̈nnöt [Borderless world: New rules for the companies and nations]. Helsinki: Suomen itsenäisyyden juhlarahasto. (in Finnish).

Rinne, R. \& Salmi, E. (1998). Oppimisen uusi järjestys [New order in learning]. Tampere: Vastapaino. (in Finnish).

Siren, V. (2009). Sibelius-Akatemian uudet käytännöt ahdistavat [The new ways of action cause anxiety in Sibelius Academy]. Saariahon puheenvuoro saa tukea kuudentoista vaikuttajan kirjelmästä [The speech of Kaija Saariaho gets support from 16 important music makers]. Helsingin Sanomat. Retrieved February 18, 2011, from http://www.hs.fi/. (in Finnish).

Toiviainen, S. (1970). Yhteiskunnalliset ja kulttuuriset ristiriidat - musikologisten osakulttuurien sosiologista tarkastelua [Society and cultural paradigms - exploring musicological subcultures from sociological point of view]. Acta Tamperensis, A(39). (in Finnish).

Weber, M. (1921/1958). The rational and social foundations of music. New York: Southern Iilinois University.

Professor of Education Ph.D. (Education)

Docent of music therapy Kimmo Lehtonen

University of Turku, Department of Education

Address: Assistentinkatu 5, Fi-20014 University of Turku, Finland

Phone: +358 405391407

E-mail:kimleh@utu.fi

Professor of Education Ph.D. (Especially pedagogy of arts and skill subjects)

Docent of Music and Arts education Antti Juvonen

University of Eastern Finland, Department of Applied Education

Address: P.O. Box 111 (Tulliportinkatu 1)

Fi-80101 University of Eastern Finland (UEF), Finland

Phone: +358 405830544

E-mail: antti.juvonen@joensuu.fi 